\title{
BRECHT AND SONGS ${ }^{1}$
}

\section{Jeffrey Gilliam²}

\begin{abstract}
It may come as a surprise that Brecht has highly developed and original ideas about how music should serve the text in his songs. Even more surprising is the willingness of those professional composers with whom he collaborated, notably Kurt Weill, Paul Dessau, and Hanns Eisler, to accept Brecht as a musical mentor.
\end{abstract}

The present document seeks to show specific ways in which these composers applied Brecht's ideas on song organisation, rhythm, and melodic shape. The study also shows how Dessau and Eisler adopted Brecht's musical aesthetics as the cornerstone of their careers as composers. Weill, however, turned to America for musical inspiration during the Hitler era, and his later songs on Brecht texts no longer follow Brecht's principle.

${ }^{1}$ For the purposes of this investigation, "Songs" will refer to those musical settings of Brecht's texts in a popular, cabaret, or commercially successful idiom. The "Kunstlied" settings of Brecht by Eisler in twelve-tone technique, for example, are beyond the scope of this topic.

2 Assoc. Professor at the University of Michigan and a visiting Professor of Music at faculty of Music, Silpakorn University, Bangkok, Thailand

\section{Introduction}

One of the most rewarding aspects of this research has been the discovery of the musical side of Bertolt Brecht's artistic personality. Who would have thought, for example, that the melody from the refrain of Kurt Weill's "Die Seeraeuber -Jenny" from Die Dreigroschenoper (The Threepenny Opera) was originally composed by Brecht himself? 
Brecht and Songs
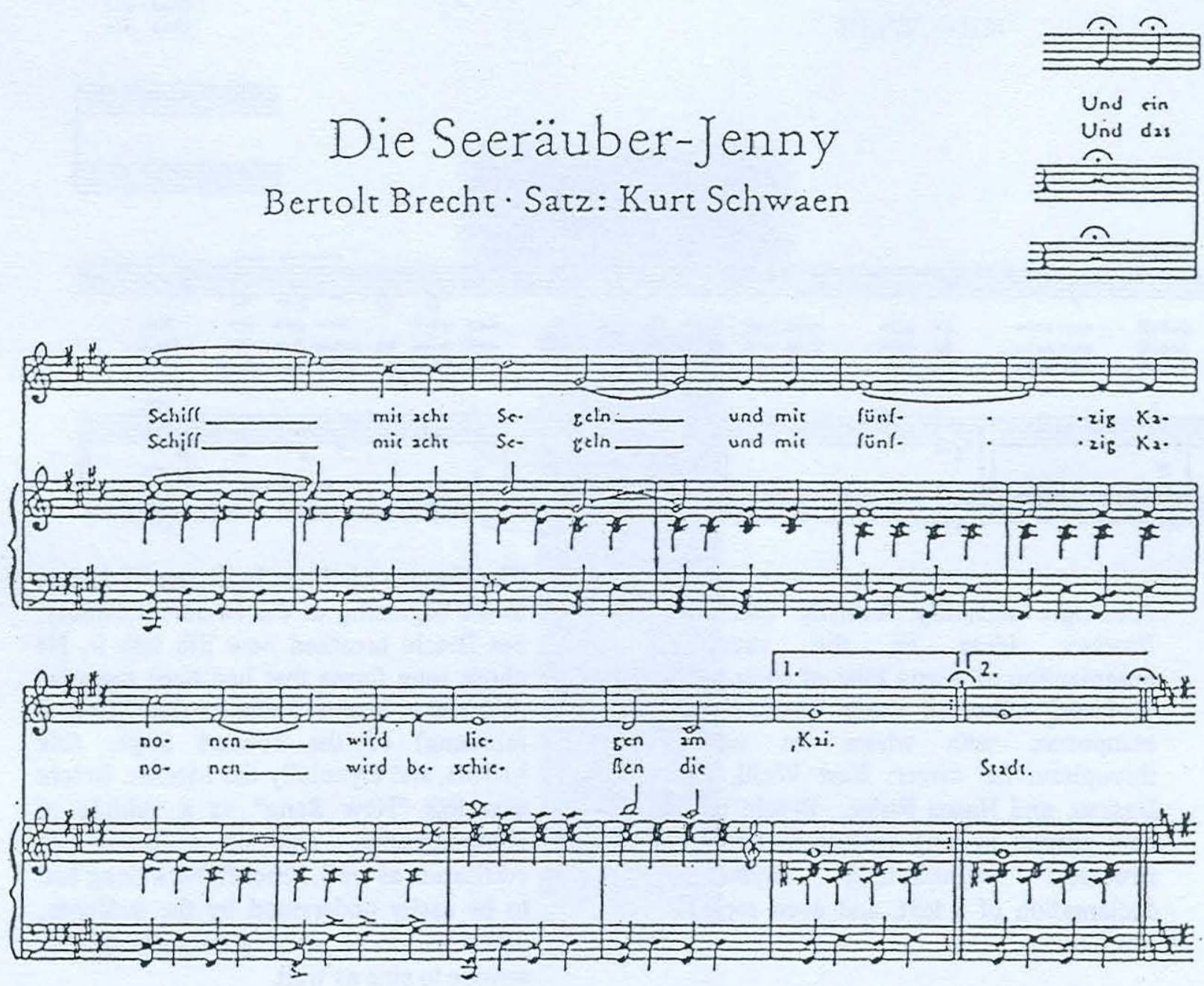


\author{
Die Seeräuber-Jenny \\ Kurt Weill
}
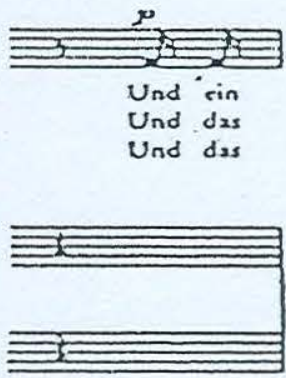
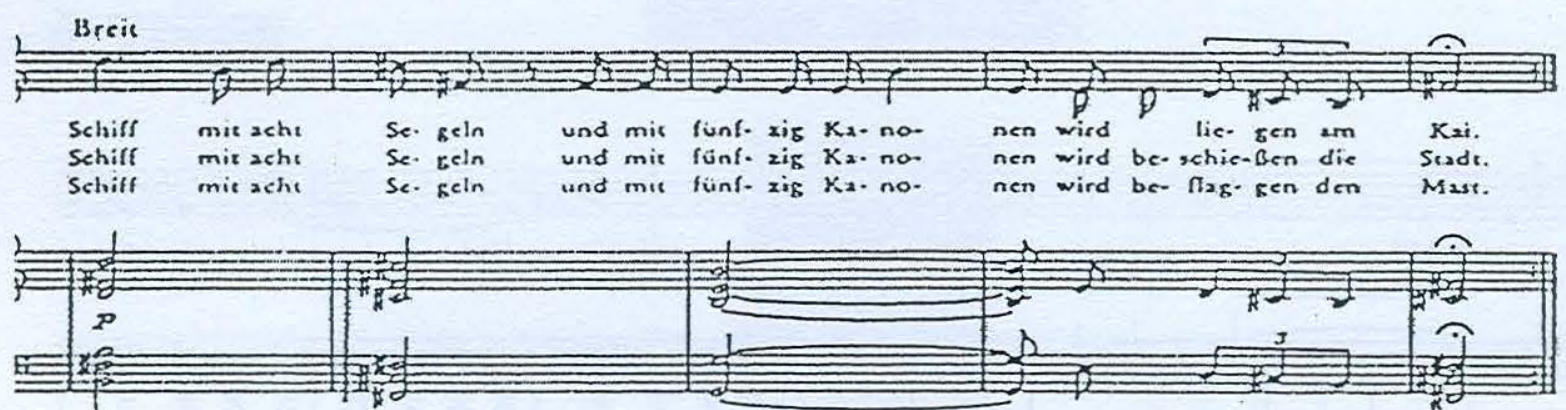

Although musically formally untrained, Brecht's ideas on the structural organization of a new kind of song had a profound effect on those "professional" composers with whom he worked throughout his career: Kurt Weill, Paul Dessau, and Hanns Eisler. Brecht broke new ground in song writing in terms of structural organization, rhythmical declamation of a text, and even melodic contour.

In art song it is always intriguing to compare two musical settings of the same poetical text. Both Franz Schubert and Hugo Wolf set Goethe's "Ganymede" to music, and both settings are regarded as great masterpieces of the German Lied. It is no less interesting when two or more twentieth century composers choose to set the same Brecht text to music, and it is especially interesting when one of the composers is Brecht himself.
The German Lied was in danger of decline at the beginning of the twentieth century, but Brecht breathed new life into it. He chose song forms that had been regarded as trivial or inappropriate for the Kunstlied (art-song) of the concert stage: folk ballads, and especially the Moritat. Brecht saw this "New Song" as a vehicle of communication, and as a means of edification as well. Brecht's New Song had to be easily understood by the audience, and it had to be vocally easy enough for anyone to sing as well.

Brecht's musical inspirations came from the marketplace, from the cabaret, and from post World War I American music. He himself took care of all of the music in his earliest plays, but then later dictated. his musical inspirations to musicians more skilled than himself, especially to Franz S. Brunier. Evyentually came the collaborations with Kurt Weill, Paul Dessau, and Hanns Eisler, lasting three, fourteen, and twenty-six years, respectively. 
In 1952 Brecht had this to say regarding his earliest musical attempts:

"Zuerst habe ich Lieder geschrieben, die ich auf der Gitarre meinen Bekannten vorsang, um ihnen und mir Spass zu machen." ("At first I wrote down songs which I sang while playing the guitar for my friends in order to provide them and myself a little fun.")

The song "Kleines Lied" ("Little Song"), also entitled "Liedlein von der Unschaedlichkeit des Alkohols" ("Little Song about the Harmlessness of Alchohol") was written by Brecht at the age of twenty in $1918 .^{3}$

${ }^{3}$ Brecht Liederbuch, Suhrkamp Verlag, 1984 p. 5 


\section{Kleines Lied}

Bertolt Brecht Satz: Kurt Schwaen
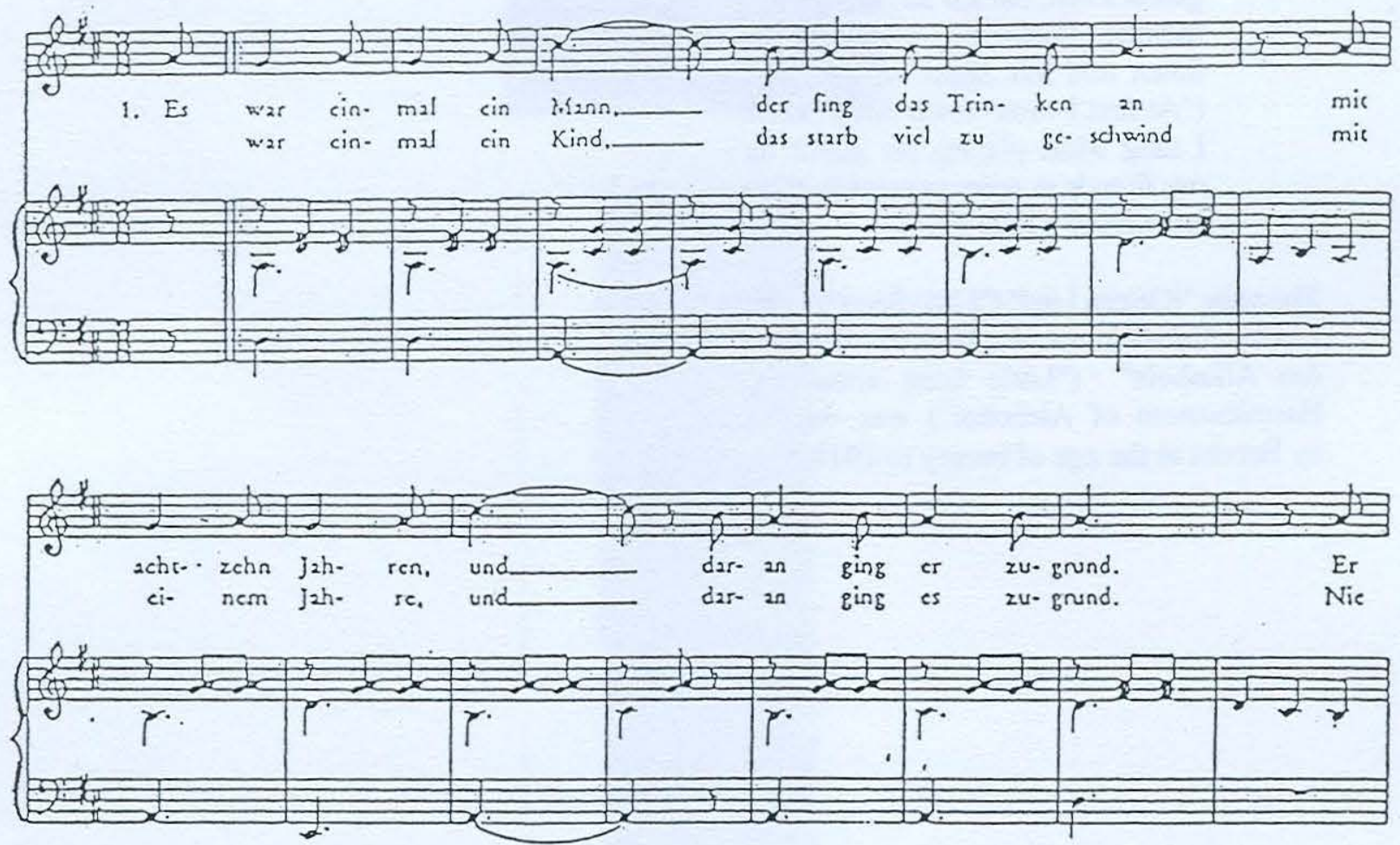

1. Es war einmal ein Mann,

1. Once upon a time there was a man, der fing das Trinken an who began to drink mit achtzehn Jahren, at age eighteen, und daran ging er zugrund.

And this led to his ruin. Er starb mit achtzig Jahr, He died at eighty, woran ist sonnenklar. Of what is clear as day.
2. Es war einmal ein Kind,

2. Once upon a time there was a child das starb viel zu geschwind that died much too quickly mit einem Jahre, at the age of one, und daran ging es zugrund. And this led to the child's ruin.

Nie trank es: das ist klar, The child never drank: this is clear und starb mit einem Jahr. And the child died at age one. 


\section{Daraus erkennt ihr wohl,}

3 . From this you all realize very well wie harmlos Alkohol.

How harmless alcohol is.

The listener is struck by the monotonous, barrel-organ style accompaniment; by the primitive, banal melody; and by the lack of any attempt at variety or sophistication in the harmony. The endless repetitions of the same text - rhythm and the total absence of any contrasting section allow the listener to focus his attention on the words and therefore on the topic of alcoholism.
German composer Paul Dessau first heard of the poem "Kleines Lied" in 1964, eight years after Brecht's death, and apparently he was astonished not to have known it. He composed his version in a single day ${ }^{4}$, and it has been described as a "moritat-like chanson with ironical bel canto insertions." 5

\footnotetext{
${ }^{4}$ Liederbuch \#105, p. 318.

${ }^{5}$ Liederbuch, p. 492.
} 

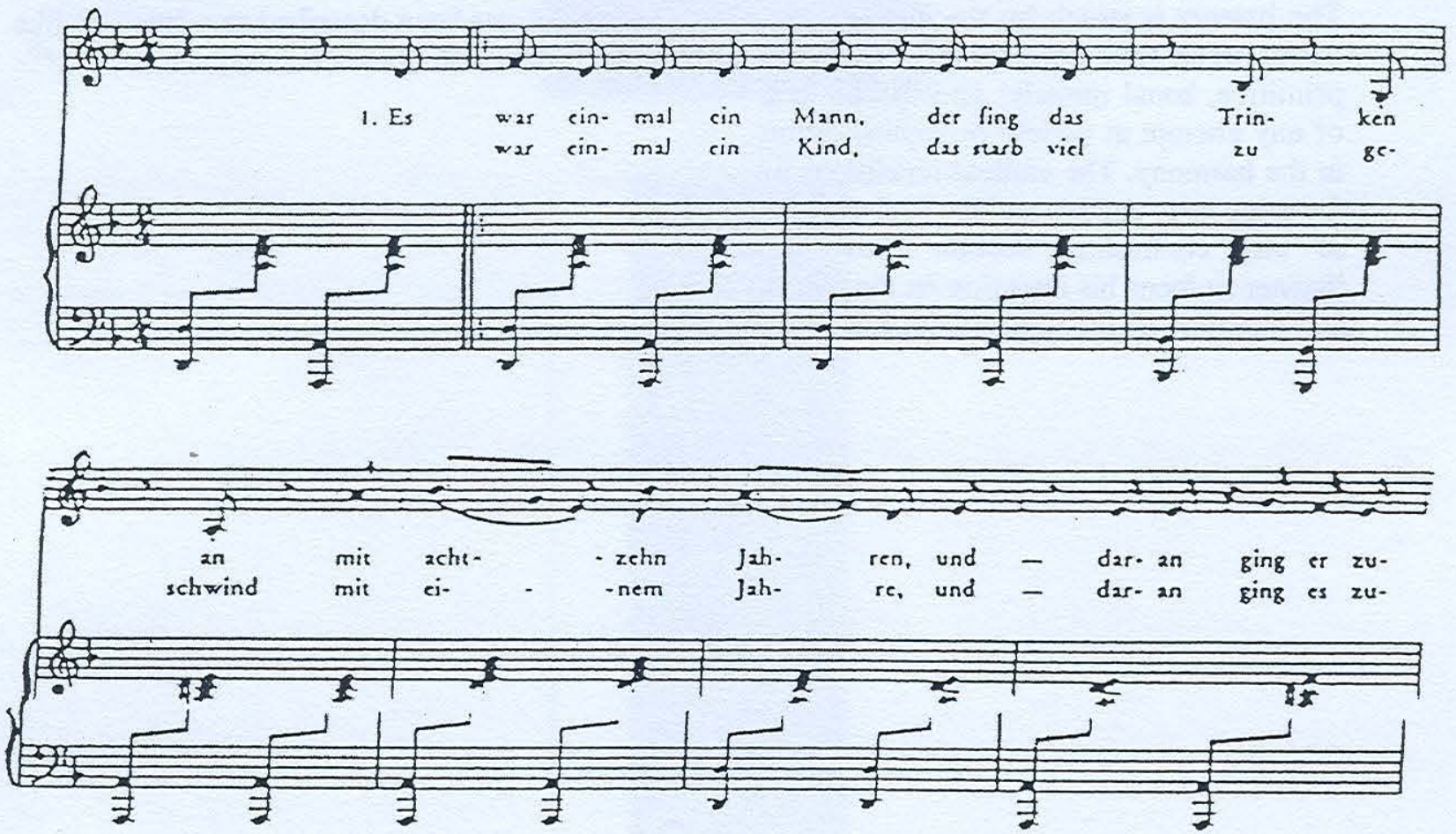

Dessau's use of rhythm is especially ingenious in his songs, even in this very simple song. Although the two-four time signature is normally clear and straightforward, Dessau's rhythmical setting of the text is anything but straightforward. He purposely puts the word "Trinken" ("drinking"), the most significant word in a song about alcoholism, on the offbeats. The second syllable of the word "zu-grund"
(English: to go down to death or destruction) receives the same treatment a few bars later. This slight, calculated time delay causes the listener to pay special attention to these words and syllables. Their seemingly false metrical placement suggests that the song itself may be slightly drunk as well. Each verse of "Kleines Lied" concludes with an abrupt and unexpected stop of the piano 
accompaniment. This is another example of Dessau's skill in effectively manipulating musical time. These silences or stops make it clear to the listener that a verse has just ended, and implies as well that something in the world of this song is unnatural and out of joint.

Dessau believed that it was important to create "contrived contradictions that must be resolved by the listener, provoking him into concern and generating a political awareness." ${ }^{6}$ Perhaps "social" awareness could be substituted in a discussion of "Kleines Lied." Dessau employs a style of vocal writing taken from Italian opera known as bel canto for two special moments in the song: the death of a one year old child (verse two); and the ironical conclusion that states how harmless alcohol is (verse three). Dessau purposely breaks Brecht's rule that a New Song must be easy to sing in order to make a point. The inclusion of a style such as bel canto Italian opera in the middle of a Brecht cabaret song is a further example of an effective, contrived contradiction that is both funny and that will cause people hopefully to think beyond their laughter.

The celebrated collaboration between Brecht and Kurt Weill lasted only three years (1927-1930), but it has left the most popular legacy, including such works as Aufstieg und Fall der Stadt Mahagonny (The Rise and Fall of the City of

${ }^{6}$ From Grove Dictionary of Music and Musicians, entry on Dessau
Mahagonny), Happy End, and especially Die Dreigroschenoper (The Threepenny Opera).

It would be too easy to imagine the young playwright Bertolt Brecht serving as mere librettist for the young composer Kurt Weill. When The Threepenny Opera was written, they were both twenty seven years old, but Brecht was at that time still in the process of articulating his new ideas about theater, while Weill had already established himself as an avant-garde composer.

A comparison of Weill's famous settings of "Die Seeraeuber - Jenny" ("Sea Pirate Jenny") and "Der Barbara Song" ("The Barbara Song") with those versions with music by Brecht himself reveals that Kurt Weill looked to Brecht for artistic guidance in the making of the New Song in terms of formal organization, pacing, and even melodic design. ${ }^{7}$

It has already been demonstrated that Kurt Weill paid Brecht the ultimate compliment by quoting Brecht's own tune, note for note, in the refrain of "Die Seeraeuber Jenny." And yet Weill took even much more from Brecht. Brecht assigned great importance to the rhythmical fixing of a text. Michael Morley, in his article Some Observations on Gestus and Gestische Musik, writes:

It seems likely that this emphasis on rhythm dates from Weill's collaboration with Brecht. After

${ }^{7}$ Liederbuch \#7, pp. 36-41 
texts. But rather than the question of who had the greater say, more interesting is the readiness on Weill's part to see the logic of this approach and to work with it.

A comparison of the Brecht and Weill musical settings of "Die Seeraeuber Jenny" and "Der Barbara Song" reveals a nearly identical rhythmical setting of both texts. $^{8}$

Die Seeräuber Jenny

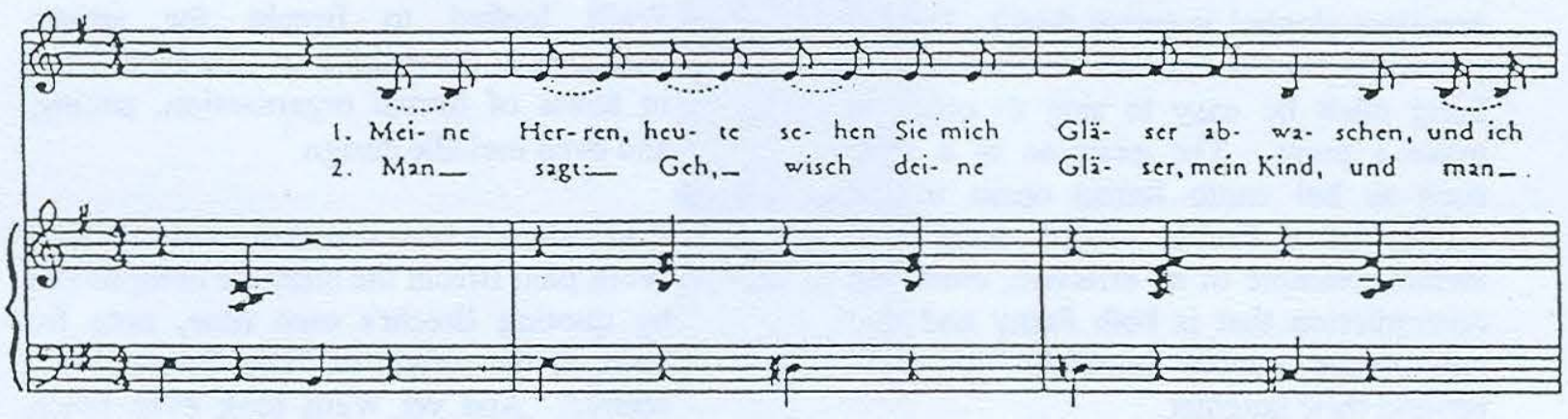

${ }^{8}$ Liederbuch \#7, pp. 36-41 


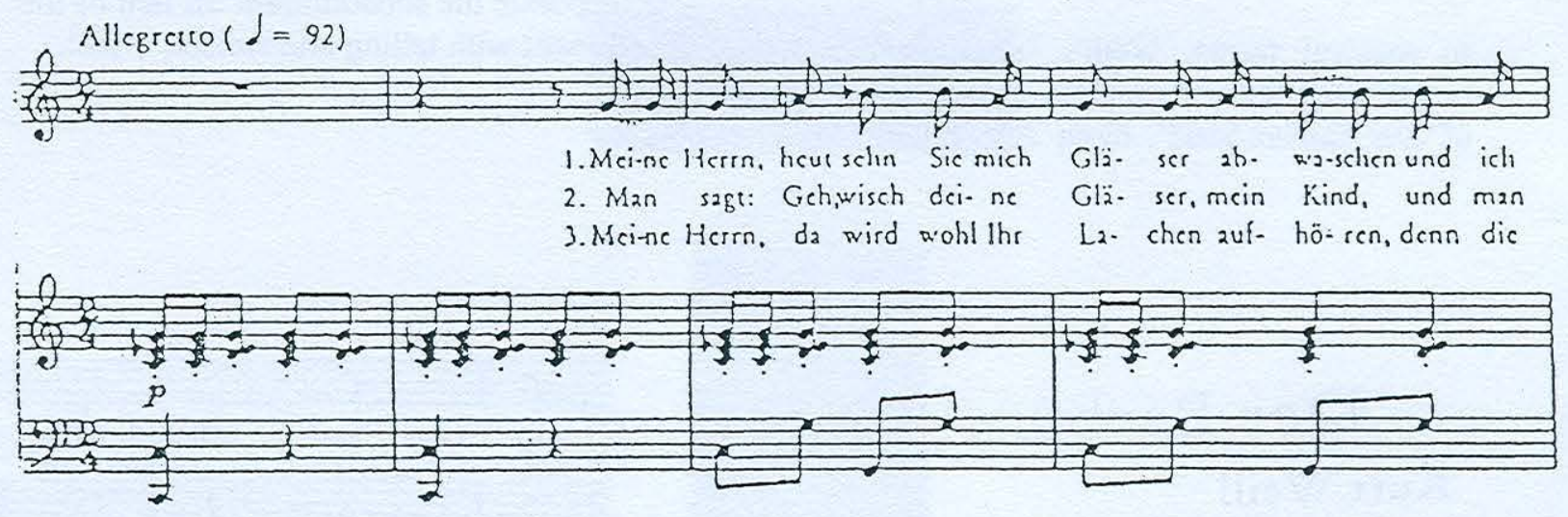

Michael Morley argues convincingly that one of the distinguishing features of a Brecht/Weill song is that the song proceeds episodically in stages rather than organically. This is accomplished in such a way as to increase the suspense all the way to the refrain. It was important for Brecht, and less so for Weill, that the speed of each episodic section would get faster as the refrain drew near. Brecht notated this by a change in time signature at the beginning of the second episode, and he is said to have asked for something called "Song-Tempo" from the musicians at the beginning of the second, slightly faster episode. ${ }^{9}$ This

${ }^{9}$ Liederbuch, \#16, pp. 32-35 phenomenon is evident in both "Die Seeraeuber- Jenny" and in "Der Barbara Song". "Der Barbara Song", for example, lays out clearly into three sections, followed by the refrain.

Ernst Joseph Aufricht, the conductor of the premiere of Die Dreigroschenoper, recorded his observations of the cast at the moment when they heard Kurt Weill play some of this now legendary music at the piano in the first rehearsal:

The small gentle man with glasses, who had a soft metallic voice that expressed exactly what he wanted to say, began to play and sing. I believe we were all put off at first, but then Vambery (a dramaturg of Aufricht) whispered in my ear 'the music has as great a chance of success as the play.' The longer Weill played, the more by bias 
against it receded. In spite of its strangeness this music had something naive, and at the same time refined and exciting about it. ${ }^{10}$

In musical terms, Weill's "strangeness" makes itself felt, for example, in the refrain of "Der Barbara Song", by an accumulation of slightly wrong or sour-sounding notes. In the bass line one would expect and alternation of tonic and dominant harmony, yet Weill manages to incorporate the subdominant in lieu of the dominant with telling and sinister effect.

\section{Der Barbara-Song Kurt Weill}
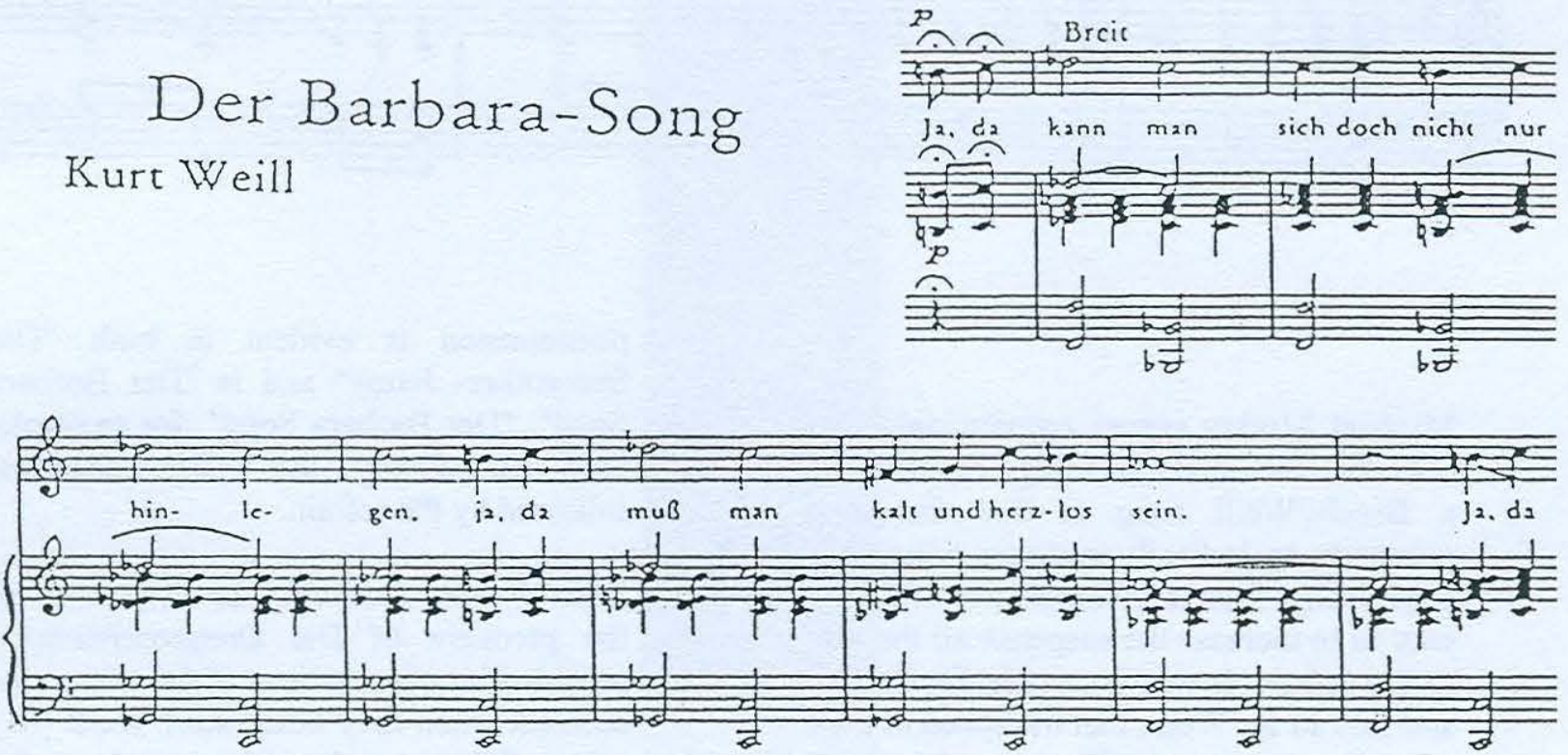

${ }^{10}$ Quote from Schebera, Juergen. Kurt Weill/ An Illustrated Life. Yale University Press, 1995, p. 107. 
Many famous Kurt Weill tunes, including the refrain of Der Barbara Song" are composed in such a way that a small number of musical pitches (four for example) are repeated many times, and the rhythmical setting of these four notes is simple, repetitive, and therefore easy to remember. An example of such as rhythm occurs in the "Barbara" refrain, and could be expressed in terms of time values as follows:

$$
\begin{array}{llll}
\text { Ja } & \text { da } & \text { kann man } \\
\text { short } & \text { short } & \text { LONG LONG }
\end{array}
$$

An almost identical melodic and rhythmical construction occurs in Brecht/Weill's most famous tune: "Die Moritat von Mackie Messer" ("Mack the Knife"):

$$
\begin{array}{llll}
\text { Und } & \text { der } & \text { Hai- } & \text { fisch } \\
\text { short } & \text { short } & \text { LONG } & \text { LONG }
\end{array}
$$

Many of Brecht's song texts present compositional challenges to the composer, in that the verses are of course all different, and often the last verse is the most different in terms of text, and yet the music often must be the same for all verses. The compositional challenge is therefore to create a music that works equally well for all verses. One solution is to slow down the tempo of the last verse in order to draw attention to its words, and this is often done by Brecht composers and performers. Another solution is to change the mode of the music from major to minor or vice versa.

In Weill's setting of "Der Barbara Song", Weill establishes himself as a consummate composer-psychologist, in that he uses the same music in all verses to describe two conflicting types of romantic/sexual behavior. In verses 1-3, Barbara communicates to the audience how innocent and decent she apparently is, as proven by her ability to refuse the overtures of the good men who court her. The music, however is in minor mode, heavily chromatic, filled with strange and sour notes, and contains an almost operatic, exaggerated pathos of expression in the refrain. The effect of Weill's music is that as the three verses progress, we doubt her innocence, or her ability to remain chaste, more and more. When she finally succumbs to a bad man in the fourth verse, the music of the refrain at last as being ideally suited to the text of this verse, and not to the previous three. It is performed slower as well, which serves to heighten the sexual overtones.

After 1930, the collaboration between Brecht and Weill began to fall apart after each of them began to publish their own separate theoretical writings on their opera, Aufstieg und Fall der Stadt Mahagonny (The Rise and Fall of the City of Mahagonny). Brecht wrote that the most important feature of the new "epic" (as opposed to the former "dramatic") theater would be a radical separation of the elements, as he and Weill had done in Die Dreigroschenoper:

The great struggle for supremacy between words, music and production...which always brings up the question, which is the pretext for what...is the music the pretext for the events on the stage, or are these the pretext for the music? ..can 
simply be by-passed by radically separating the elements. ${ }^{11}$

Weill, on the other hand, did not want to see such a radical separation in "epic" opera. In his mind, and this may not come as a surprise, it was music which played the most important role. Kurt Weill left Nazi Germany for France in 1933, and he settled for good in New York City in 1935.

In 1935, the Nationalsozialistische Monatsheft, a Nazi monthly publication, described Weill and Brecht as follows:

The most conspicuous aspect of Weill's music is jazz rhythm. (If) Weill is intentionally bringing Negro rhythms into German art music. So the people that brought forth a Bach, Mozart, Beethoven, and Wagner need to be rejuvenated with Negro blood! In summary one can only say over and over that Brechtian texts and Weillian music are never to be regarded as German art. 12

During the Nazi regime, Brecht and all of his composers devoted considerable energy to the writing of anti-Nazi songs. In 1943, Kurt Weill set Brecht's text, "Und was bekam des Soldaten Weib?" ("And What Did the Soldier's Wife Get?") A recording has survived with Kurt Weill at the piano accompanying his beloved Lotte Lenya. The poem takes a sarcastic and scathing look at

${ }^{11}$ Kurt Weill/ An Illustrated Life, p. 148.

${ }^{12}$ Kurt Weill/ An Illustrated Life, p. 204. the subject of plunder in the capital cities of those European countries ravaged by the Nazi invasions. Brecht links the names of the cities with the gifts the soldiers' wives received from them, culminating in the final verse about Russia. Because of course Russia was the beginning of the end for Hitler, the soldier's wife receives, appropriately, the widow's veil to close the song.

Beginning in 1939, Kurt Weill shifted his musical talents away from "serious" European style composition, and more toward Broadway and Hollywood. This shift in priorities is evident in his setting of this text. Weill seems content to compose in essence a Broadway song here, despite the seriousness of the text. Granted, Weill's setting alternates between major and minor mode (as do several of his earlier songs as well), and the tempo is rather slow and funereal, communicating that things will not turn out well in the end. This device, however, seems to numb instead of heighten the listener's sensitivity to the text as the song proceeds towards its rather formulaic, cocktail lounge style conclusion in major mode.

Weill also seems less than acutely sensitive in this rhythmical setting of the text. His rendition accentuates unimportant syllables, leading one to the uncomfortable conclusion that the words and the music only more or less fit together:

Weill: Was be-KAM des Sol-DAten WEIB?

Instead of: WAS bekam des Soldaten Weib? (as in Eisler) 
The subject matter of this song greatly interested and upset composer Hanns Eisler, who had fought in World War I. In a public debate with Brecht, he succeeded in effecting a transformation in the song's title, from "Und was bekam des Soldaten Weib?" ("And What did the Soldier's Wife Get?") to "Und was bekam des SA-Manns Weib?" ("And What did the Wife of the SA Man get?") to the final version: "Das Lied vom Weib des Nazisoldaten". ("The Song of the Wife of the Nazi Soldier.")

The collaboration between Eisler and Brecht was an important and enduring one. Eisler composed classic marching songs of the socialist movement (for example "Solidaritaetslied" ("The Song of Solidarity") from the film Kuhle Wampe. He was trained as a composer in the style of the Second Viennese School, and Amold Schoenberg thought highly of his work.
Eisler has set numerous texts of Brecht in both tonal and non-tonal idioms. Brecht described Eisler's music as follows in 1935:

Die Musik Eislers ist keineswegs das, was man einfach nennt.

Sie ist als Musik ziemlich kompliziert, und ich kenne keine emsthaftere als sie.

(The music of Eisler is in no way anything that you could call simple. As music it is quite complicated and I know of no music that is more serious.)

It is all the more remarkable when an extremely intellectual composer such as Eisler is willing to let all of that sophistication go in order to get to the heart or gestus of a text such as "Das Lied vom Weib des Nazisoldaten."

Hanns Eisler

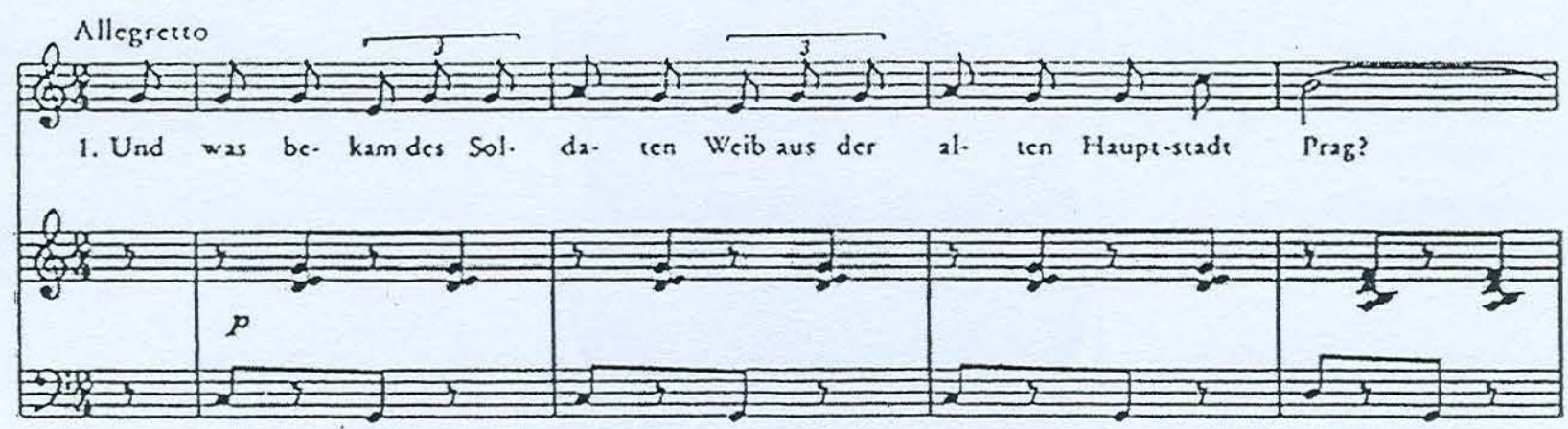


Eisler quotes Stephen Foster's "Camptown Races" in his melody, and the two pianos in his version, having been prepared with thumbtacks in the piano hammers, create a sound reminiscent of a saloon from the American Wild West. Michael Morley writes that the text suggests a simple folk song or round, and its recurrent linking of the names of cities with the giits suggests an up-tempo, briskly moving setting rather than the more deliberate and musically sophisticated idiom chosen by Weill. Performer/chanteuse Gisela May was apparently instructed by Eisler to deliver the text, "Das bekam sie aus der Stadt...." ("That's what she got from the city of ....") with the utmost vulgarity, so as to make the contrast to the last verse as effective as possible. Eisler's songs are known for their "throwaway" surprise endings, and the shock of the widow's veil in the last verse sets up an abrupt and brutal close to this song.
In 1943 Brecht was taking a walk with composer Paul Dessau, and Brecht sang to him part of another anti-Nazi song called "Lied einer deutschen Mutter" ("A German Mother's Song"). Just as Kurt Weill had taken an entire melody note for note from Brecht, Paul Dessau's task was to incorporate exactly one phrase from Brecht into his otherwise original composition: "Haett' ich gewusst, was ich heute weiss" ("If only I'd known what I know today"). Dessau apparently found this very difficult to do, because Brecht's contribution is in the middle of each verse. 
Brecht and Songs

Lied einer deutschen Mutter

Für Helene Weigel

Paul Dessau
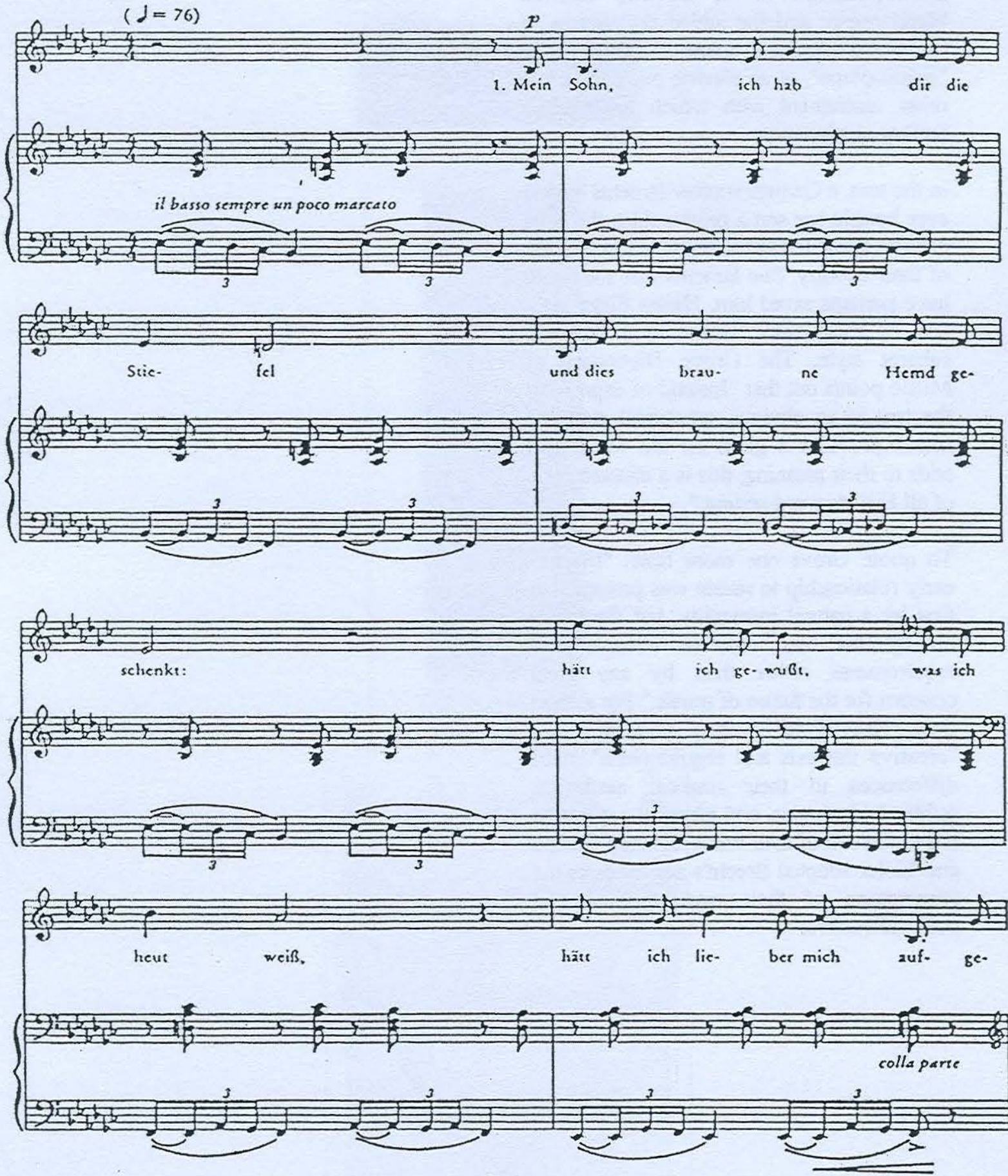
Brecht was delighted with Dessau's setting, particularly with the elaborate accompaniment. The sound of the accompaniment is of Brecht's beloved barrel-organ, and the added thumbtacks in the piano hammers create the sound of a "guitar-piano", or an electric piano, or some other instrument with which to create a feeling of alienation.

In the text, a German mother laments having ever bought her son a brown shirt; the Nazi path he chose led to his death and to the ruin of their country. She laments that she could have perhaps saved him. Hanns Eisler set a few of these same verses in a heartfelt, cabaret style. The Grove Dictionary of Music points out that "Instead of expressing the text in an obvious, emotional way, the music provides a gloss on the words and adds to their meaning, this is a characteristic of all Eisler's word-setting."

To quote Grove one more time: "Brecht's early relationship to music was prompted at first by a natural musicality, but from then on by his own creative interests and requirements rather than by any great concern for the future of music." For a short time, Kurt Weill was a part of those "creative interests and requirements", until differences in their musical aesthetics, political ideologies, and physical separation led to the end of their work together. Dessau and Eisler adopted Brecht's aesthetics as the cornerstone of their own musical and political careers. 